[辳化 第 43 巻, 第 3 号, p. 177 182, 1969]

\title{
アミロデキストリンの結晶化に及ぼす植物抽出液の影響
}

\author{
鈴木綾子, 檜作 進*, 二国二郎** \\ (大阪女子大学, *鹿児島大学農学部, **大阪大学産莱科学研究所)
}

昭和 43 年 9 月 14 日受理

\section{The Effect of Plant Tissue Extracts on the Recrystallization of an Amylodextrin}

\author{
By Ayako SuzUki, Susumu HizUkuRI*, Ziro NikUNI** \\ Osaka Women University; * Faculty of Agriculture, Kagoshima University; \\ **Institute of Scientific Industrial Ind. Research, Osaka University
}

\begin{abstract}
An amylodextrin specimen (DP. 14.5), which was separated from a commercial dextrin syrup, was recrystallized from clear aqueous extracts of various plant tissues_-potato, sweet potato, pea, broad bean, corn, chestnut, lotus tuber, cabbage leaf and wheat flour.

Under the same concentration and temperature, the type of $X$-ray diffraction patterns of all these recrystallized specimens shifted to $A$ type side to some different extents from $\mathrm{C}_{B}$ type of the standard specimen, which was recrystallized from distilled water, even when the concentration correction was made corresponding to the solid substances of the tissue extracts.

The yield of these recrystallized amylodextrin from the plant tissue extracts was more than twice than that of the standard.

It is concluded that all plant tissues examined may contain a substance or substances, which shift the X-ray diffraction pattern to $A$ type side and accelerate the precipitation of the amylodextrin.

(Received September 14, 1968)
\end{abstract}

\section{はじめに}

デンプン粒は，植物の種類により A, B および中間の C形に区別されるいずれかの結晶構造をるつことが知ら れている，著者らはこれまでに，デンプン粒の結晶構造 がその植物の環境温度に依存することを種々の植物につ いて証明してきた. しかし，この温度の影警は植物の種 類によって特徵があり，同一温度でも同一の結晶形を与 えるのではない.たとえば, $20^{\circ} \mathrm{C}$ の場合ジャガイモでは B形, 発芽大豆ではC形, 米ではA形の結晶形のデンプ ンが得られる(1 4).

この相違の原因の一つが，細胞液の組成の相違に基つ くものではないかと考えて，次のよ5な春験をおこなっ た.すなわり、アミロデキストリンの一定量に種々の植 物組織の抽出液の一定量を加え，一定温度で結晶化し， その結晶形をX線ディフラタトメーターで調ベた。そとの 結果，対照として抽出夜の代わりに水を用いた場合， $\mathrm{C}_{\mathrm{B}}$
形の結晶形のものが得られたが，植物㹨出液を用いると， いずれの場合も結晶形が水の場合よりもA形の方向に変 化することが認められた．また再結の際のアミロデキス トリンの収量は，水の場合に比べ植物抽出液を用いた力 が 2 倍，あるいはそれ以上となる。

\section{実 験 方 法}

1. 試料のアミロデキストリンの調製と性質： 約 10 年前, 酒の三倍醇造用として製造された松谷化学工業株 式会社製デキストリン（商品名 MLD）は，水分約 20\%， 糖の平均重合度的 4.2 のシラップでする(5)，これを放置 すると白濁を生ずる。著者らは約 8 年間二国研究室に保 管した前記 MLD 約 151 を既報に準じて (5)処理して白 溜物質であるアミロデキストリンを集めた。すなわり， この白濁したシラップに 4 倍量の玲水を加文て愐抖し， 白濁物質を遠心分離した，得られた白色沈叚をさらに数 回，遠心分陮法で泠水を用いて洗浄した，次いで 99\% 
アルコールで脱水後，エーテルで洗い，壏化カルシウム デシターター中で茈懆した。

このようにして得られた粉末試料を濃度 $40 \%$ 程度に 温水に溶解し，活性炭を加光遠心分離し，濾過後濾液に 同量の $99 \%$ アルコールを加充，空温 $\left(20^{\circ} \mathrm{C}\right)$ に3 時間 静置後，泠蔵庫中 $\left(5^{\circ} \mathrm{C}\right)$ に 7 日間和いた。できた白色沈 殿物を $85 \%$ アルコールで洗浄し，99\%アルコールで脱 水後, グラスフィルターで濾過し，最後にエーテルで洗 浄後塩化カルシウムデシケーター中で乾燥した，水分は $15.7 \%$ であった．分析の結果，このものは平均重合度 14.5 のアミロデキストリンで， $\beta$ アアミラーゼによる分 解限度は78\%であった．前報(5)では $\beta$-アミラーゼ分解 限度を $100 \%$ と報告したが，前回使用した $\beta$ ーアミラー

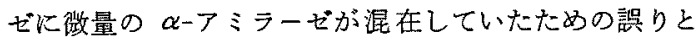
思われる，数回にわたる分解実験と，竹田靖史（鹿児島 大学) がサッマイモから純化した結晶 $\beta$ アミラーゼに よる本実験の結果とから，ここに訂正する。

重合度は全糖量を Anthron 法で，薑元糖は SomogyiNelson 法(6)（たたし，銅試薬と 30 分加熱した）で測定 して算出した。いずれも，グルコースを標準とした。

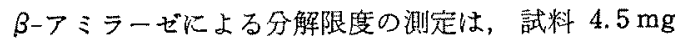
を含さ酢酸緩衝液（pH 4.8）1 ml にサッマイモの結晶

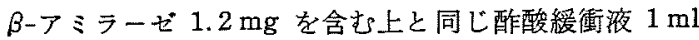
を加えて，トルェン添加の下に $37^{\circ} \mathrm{C}$ で行なった．分解 は 1 時間以内に極限に澾し，以後 6 時間にわたって一定 であった，還元力は Somogyi-Nelson 法で測定し，結 果はマルトースへの分解率として算出した。

2. 植物抽出液の調製法：植物の種類は、ジャガイ モ，サッマイモ（高系 14 号，ゴコク，コナセンガン， タマユタカ)、エンドウ, ソラマメ,トウモロコシ,クリ, レンヌン，キャベッ，小麦である、サッマイモの各種は 三重大学串学部付属農場産のものを, その他は市肘のる のを用いた. 小麦としては市販小麦粉を材料とした。

抽出方法は，試料を等重量の水ととるに、ミキサーで 1 分間処理して得た汁液を二重のガーゼを通して搾汁し 組織片を除いた。この搾汁液を $10,000 \mathrm{rpm}$ で 10 分間 遠心分離してデンプンを含む不溶物を除いた上澄液を， 沸と5水中で 3 分間熱処理してデンプン分解醭素などを゙ 不活性化した。このとき生じた不溶物を $10,000 \mathrm{rpm}$ 10 分間遠心分離して除去したものを抽出液として使用 Lた.

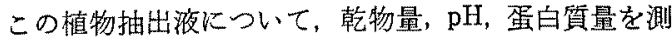

定した，蛋白筫量は，便宜的に牛血清アルブミンを標準 として, Lowry 法 ${ }^{(7)} に よ り$ 比較定量した.

3. アミロデキストリンの結晶化：アミロデキスト リン（水分含量 $15.7 \%$ のまの重量） $850 \mathrm{mg}$ に植物 抽出液を $1.25 \mathrm{ml}$ 加え，よく振とうし，沸とう水中で 90 秒加熱して完全に溶解後， $12^{\circ} \mathrm{C}$ に急冷し同じ温度のフ ラン器中で 48 時間結晶化した。結晶温度を $12^{\circ} \mathrm{C} と し$ た理由は、アミロデキストリンの結晶形は結晶化のとき の濃度と温度に完全に依存することが明らかである ${ }^{(8)}$ の で子備实験を行ない，前記の濃度で結晶形の变化を認め やすい温度条件を検討し， $12^{\circ} \mathrm{C}$ と定めたのである。でき た沈殿をグラスフィルターで濾過し，冷水で洗浄後 $98 \%$ エチルアルコールで脱水，さらにェーテルで洗浄し乾燥 した.

4. X線ティフラクトメーターの操作条件：理学電

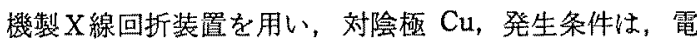
压 $35 \mathrm{kVP}$ ，電流 $12.5 \mathrm{~mA}$ で発生 $\mathrm{X}$ 線はニッケル箔を用 いてK $\beta$ 楾を除去した. Ratemeter は, scale factor 16 , multiplier 1 , time constant 2 秒とした。スりット系 は，発散スリット $1^{\circ}$, 受光スリット 0.15 , 制限スリット 1のものを埰用した，G-M 管の走査速度は，1\%分，紙 速度は， $1 \mathrm{~cm} /$ 分とした。

\section{実 験 結 果}

結晶化に用いた植物抽出液の組成は第 1 表にあげる.

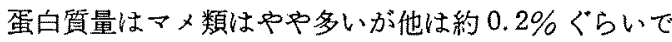
あり，乾物量は，小麦，クリは多いが，他は約 $3 \%$ 前後 である．pHは植物の種類で多少異なるが大差はなかっ た.

これらの植物抽出液を用いて結晶化したとき，対照と して水を用いると $\mathrm{C}_{\mathrm{B}}$ 形の結晶形のものが得られるが， 植物抽出液を用いると，ジャガイモ，レンコン，キャべ シは $\mathrm{C}_{\mathrm{C}}$ 形の結晶が得られ, エンドウ, ソラマメ,トウ モロコシ, クリ，小麦は， $\mathrm{C}_{\mathrm{A}}$ 形のbのが得られた。 こ れら各種のX図形のうち，その代表的なるの3種だけを

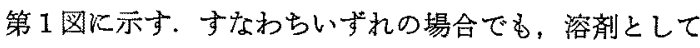
水を用いるよりる植物抽出液を用いた方がアミロデキス トソンの結晶図形を $\mathrm{C}_{\mathrm{C}}$ 形をへて $\mathrm{C}_{\mathrm{A}}$ 形の方向に押しゃ っている. サシマイモ抽出夜のように、この程度が品種 によって異なるものもある。ざコタ，コナセンガン，夕 マユタカは $\mathrm{C}_{\mathrm{A}}$ 形の結晶形だが，高系 14 号は $\mathrm{C}_{\mathrm{C}}$ 形の 結晶形であった（第 2 表の第 I欄）。

しかし，植物抽出液中には，第1表に示したよ5に， 
分量の異なる種々の溶存物があり，それがアミロデキス トリン溶液の濃度を高めたことになるための影響が䓔克 られる，皁こで，次固形物量が $3 \%$ 以上の植物抽出液 を兄らび，そ机らの固形物量が全部 3\% となる上う稀釈

第 1 表 植物抽出液中の㪕物量, $\mathrm{pH}$, 扰よび 蛋白筫量

\begin{tabular}{|c|c|c|c|c|c|}
\hline \multicolumn{3}{|c|}{ 植物抽出夜 } & 乾物 量 $(\%)$ & $\mathrm{pH}$ & 蛋白質量 $(\%)$ \\
\hline$\dot{z}$ & †ガイ & $\mp$ & 1.6 & 6.1 & 0.20 \\
\hline サ & (高系 14 & 号 & 3.8 & 6.2 & 0.17 \\
\hline \% & $\Rightarrow \quad=$ & $\Rightarrow$ & 2.6 & 6.0 & 0.14 \\
\hline 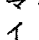 & コナセン & ダン & 2.8 & 6.2 & 0.17 \\
\hline 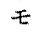 & 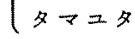 & 力 & 3.2 & 6.3 & 0.14 \\
\hline I & ン & ウ & 3.2 & 6.7 & 0.73 \\
\hline y & $\checkmark$ & $x$ & 2.8 & 6.5 & 0.67 \\
\hline r & ウモロコ & $\ddot{*}$ & 3.0 & 7.6 & 0.18 \\
\hline$\eta$ & & $y$ & 5.6 & 6.3 & 0.28 \\
\hline$v$ & $=$ & y & 2.7 & 6.1 & 0.25 \\
\hline$\neq$ & $\ddot{n}$ & ッ & 2.1 & 5.6 & 0.10 \\
\hline 小 & & 麦 & 6.8 & 5.9 & 0.66 \\
\hline
\end{tabular}

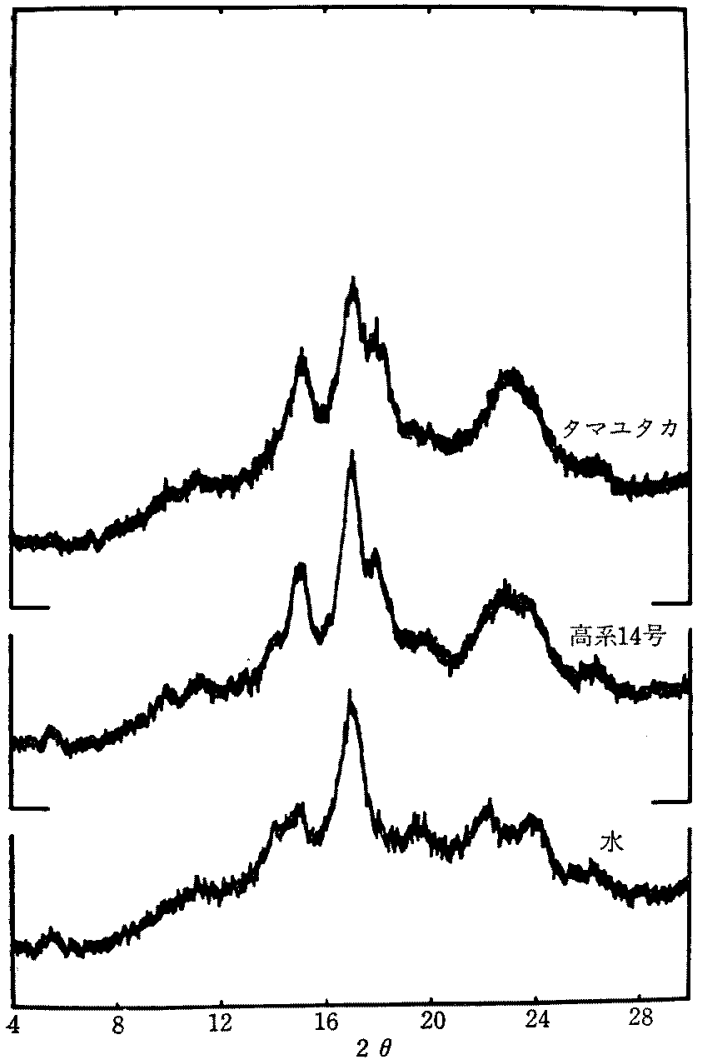

第 1 図 サッマイモ抽出液の種頪によるアミロ デキストリンの結晶図形

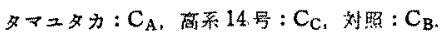

し，この一定固形物を含む稀釈液を用い前同様の方法で アミロデキストリンを結晶化した。.たたし、ジャガイモ とレンコンは前記 2.の調慗法によると固形物がそれぞ れ $1.6 \%$ と $2.7 \%$ の抽出液が得られるが，同一原料を そのま削り下して得た汁洨につき 2 ，の方法を用い， やや濃厚な液を得，これをらすめて固形物量が3\%にな るよう抽出液を調製した，その結果を第 2 図と第 2 表の 最右欄（II）に示す．なお，この場合は，抽出夜の固形物 量 3\%に相当する量のアミロデキストリンを追加した水

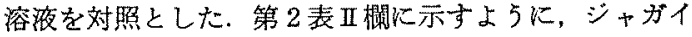
モとレンコンでは明らかに固形物を增加した影響が出て, いずれるI欄の $\mathrm{C}_{\mathrm{C}}$ から $\mathrm{C}_{\mathrm{A}}$ へと図形が変化した。また 固形物 $6.8 \%$ 上浱厚であった小麦粉抽出液では $3 \%$ への 稀橎の影響が表われて $\mathrm{C}_{\mathrm{A}}$ だったものが $\mathrm{C}_{\mathrm{C}}$ となり， B 形に近づいた，クリには大した变化が認められなかっ

$(3 \%$

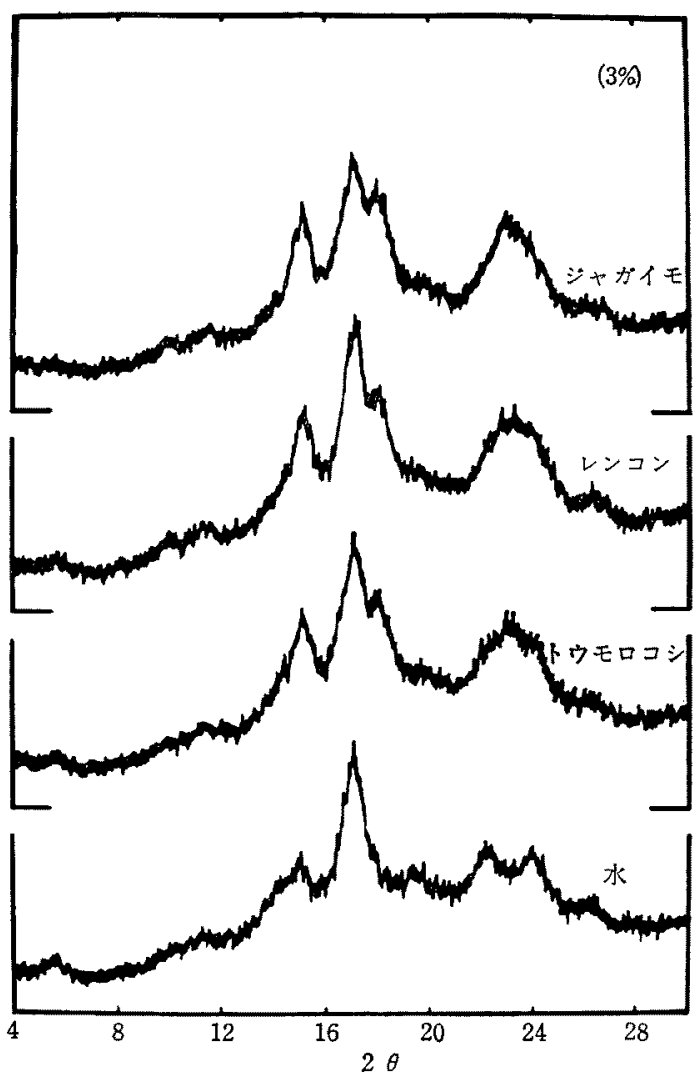

第 2 因植物抽出液中の固形物を $3 \%$ にした場合の アミロデキストソンの結晶図形

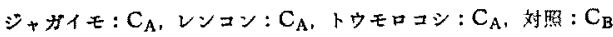

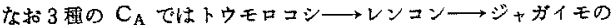
譄てA班に近ひ、ている。 
第 2 饻 植物抽出液によるアミロデキストリン の結晶形

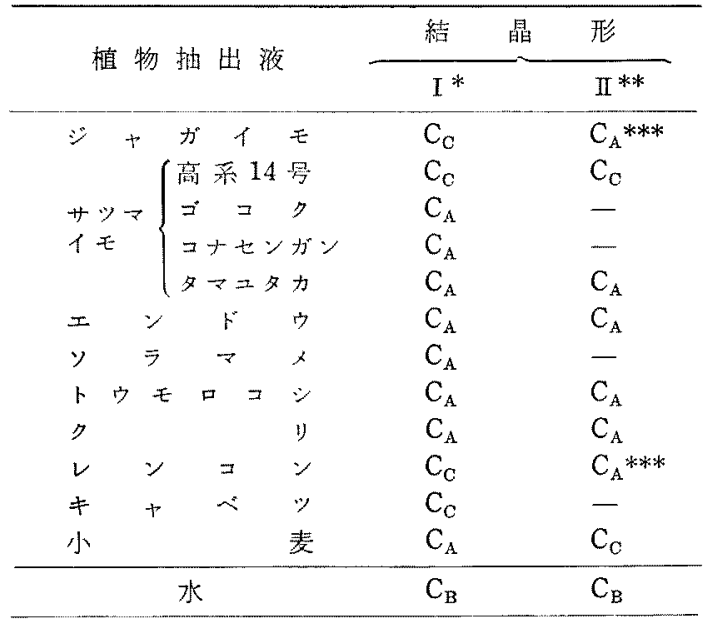

*椎物独出波そのまきを用いて絬晶化した場台

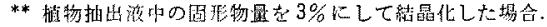

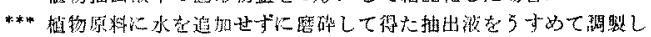
t。

た、その他休稀釈の度も少なく大した図形の变化はなか った。

また詨照の水溶液では， $3 \%$ の固形物量に相当するフ ミロデキストリンを增量して濃度を上け゚たが，とくに認 め得后汪ど变化は出て和らず，你然として $C_{B}$ である (第 1 図と第 2 図の水溶液の図形参照).このよ5に固形 物の濃度の差による影艟を除去してる，な㨁物抽出液 中にはアミロデキストリンの結晶図形をA形の方へ押し やる物質の存在が確かめられた。

この点をさらにはっきりさせるために，最む固形物の 多以小麦粉抽出液の固形物量を $6.8 \%$ から $4 \%, 3 \%, 1$ \%と順次うすめたものを使用して，同様のアミロデキス トリン濃度で結晶化した．水の場合も同じく $6.8,4$,

$3,1 \%$ の固形物に相当するアミロデキストリンを追加し た溶液を用いて結晶化したすすなわら，小麦粉抽出液と それぞれ固形物量を等しくして比較した。その結果の一 部を第 3 図に示す．水の場合はアミロデキストリン追加 量が多くなるにつれ，また小麦粉抽出液の場合は固形物 量が多くなるにつれ，いずれも傾向としてはA形に近づ くが，氷の場合には 3 者とも依然として $\mathrm{C}_{\mathrm{B}}$ であり，小 麦粉抽出液の $4 \%$ と $6.8 \%$ 固形物の場合の $\mathrm{C}_{\mathrm{A}}$ 図形之 は明らかに異なっている。

このよ5に，植物抽出夜中にアミロデキストリンの結 晶化に影響し，A形の結晶形に近づけさせる物質が存在 していることが明らかになったが，この物質を検索する

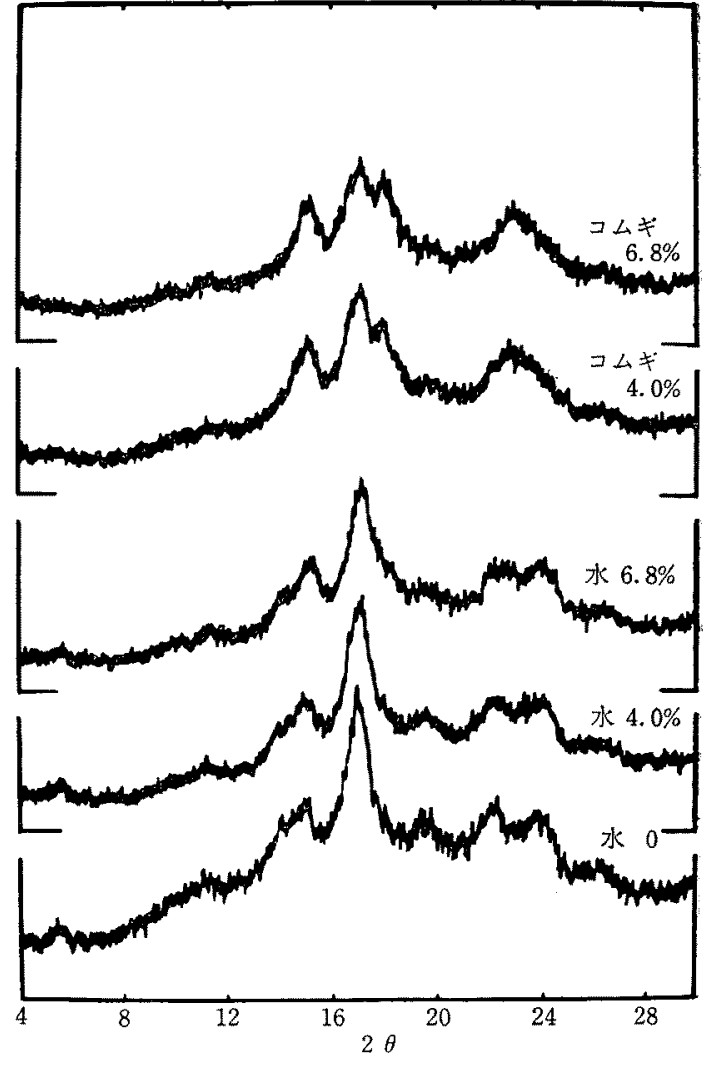

第3図小麦粉抽出渡の謴度を変えた場合とその固 形物に相当寸るアミロデキストリンを追加し た水溶液の場合の結晶図形（祱明は本文中）

ために2，3 の実験を行なった。

まず，脂貿の影響を考えて，エンドウ抽出液とジャガ イモ抽出液とをそれぞれ抽出液と同量のエーテルで 2 回 抽出し，エーテル可溶物を除いた水檿を沸と5水中で, しばらく加熱して残存エーテルを除いた抽出液でアミロ デキストリンの結晶化を試み，その再結物をX線回折法 で試験した。.ジャガイモ抽出液の場合も，エンドウ抽出 液の場合もエーテル処理の影響がみ上められなかった。

さらに，植物抽出液に含まれている無機塩類の影響を 調べるために，植物中に常成分として含まれていると考 光られる $\mathrm{KCl}, \mathrm{K}_{2} \mathrm{HPO}_{4}$ と，植物中にはないが結晶形を A形とする代表的な舆機塩(9)である KI の3者を選び， 各々 $3 \%$ 水溶液としてアミロデキストリンの結晶化を 試みた，先の結果， $\mathrm{KCl}$ と $\mathrm{KI}$ 溶液では完全にA 形， $\mathrm{K}_{2} \mathrm{HPO}_{4}$ 溶液では $\mathrm{C}_{\mathrm{A}}$ 形となり，非常に強い影響を示し た（第 4 図）。すなわら，植物抽出液中に含まれる数\% 


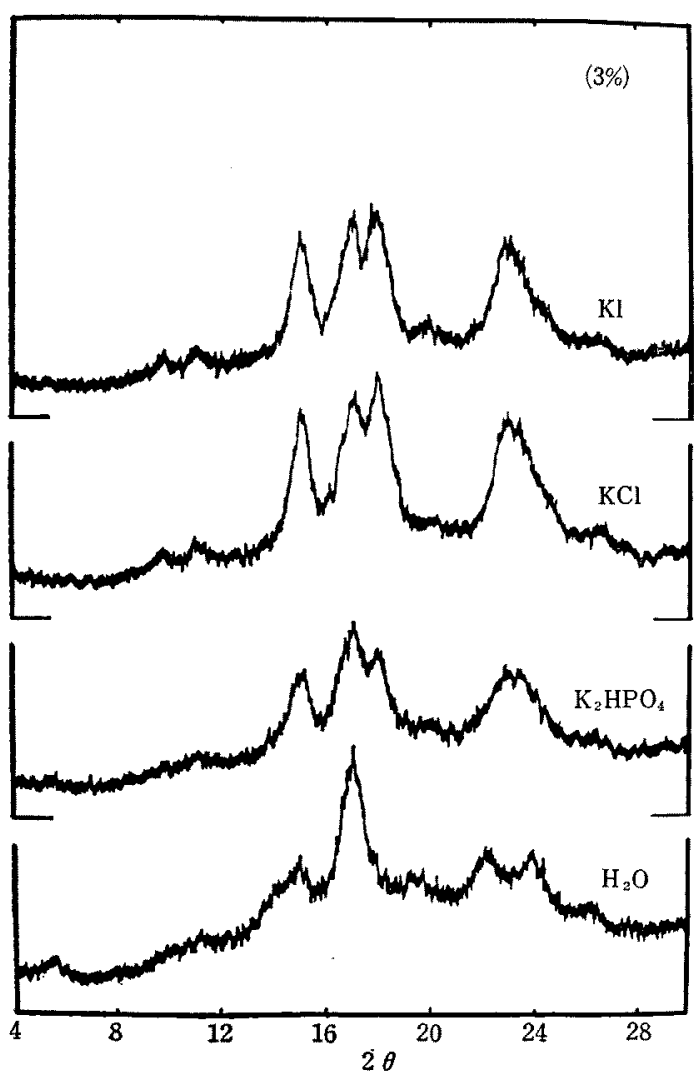

第 4 図無機塩類溶液のアミロデキストリンの結晶図形 $\mathrm{KI}: \mathrm{A}, \mathrm{KCl}: \mathrm{A}, \mathrm{K}_{2} \mathrm{HPO}_{4}: \mathrm{C}_{\mathrm{A}}$, 対热: $\mathrm{C}_{\mathrm{B}}$.

第 3 表 フミロデキストリンの沈殿量と植物 抽出液の関係

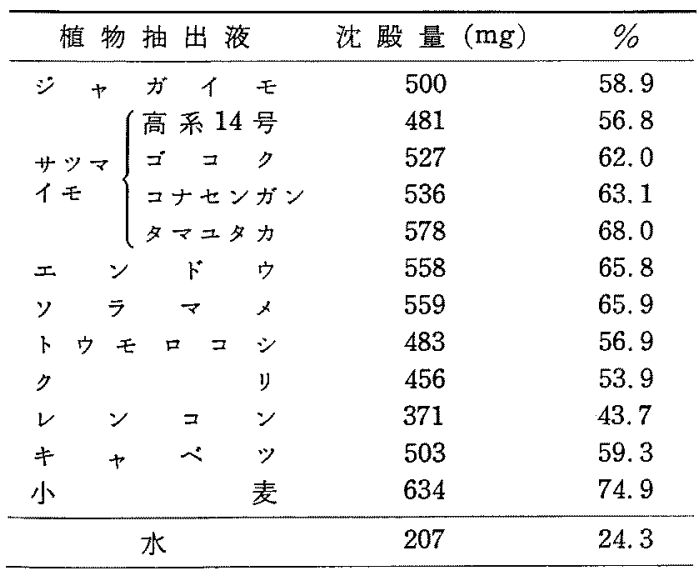

の固形物のうち，無機塩類がX線图形に相当影響するこ とが推定される。

最後に，以上の種々の植物抽出液でアミロデキストリ
ンを結晶化したとき，沈殿量が抽出液の種類によってか なり相違することがみとめられたので，第 2 表 I 欄に示 した結晶化の際の母液の全糖量を測定して，液に残っ たデキストリン㷐を求め、これからアミロデキストリン の沈段量を算出した，その結果が第3表である，この際 は，対照の水の場合，抽出液の固形物に対する濼度差の

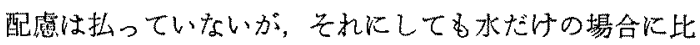
ベて結晶として沈股したアミロペクチンの量が蔽しく多 い．蓑た固形物量のとくに多い小麦粉抽出液の場合を除 いて，抽出液中の固形物の多少による差が，さほど認め られないすすなわら，植物抽出液中にはアミロデキスト リンの結晶形をA形の方へ押しやる性質の物質が含まれ ていると同時に，アミロデキストリンの晶出を促進する 物質も存在するものと推定される.

考察

以上の寒験で，水を用いた場合はアミロデキストリン の $\mathrm{C}_{\mathrm{B}}$ 形の結晶形のすの゙得られる濃度と温度の再結条 件の下で, 水の代わりに同量の植物抽出液を用いると， いずれの場合も，アミロデキストリンの結晶形がA形の 方向に変化し，その程度が植物の種類によって異なっ た.

この事実は植物抽出液中に何かアミロデキストリンの 結晶化に影響を与える物質が存在していることを示晙し ている，この物質は少なくとる抽出液のエーテル処理に よっては除かれないままた無機イオンの在在が大きな影 響を与えることは，すでに示されている実事(9)であるが， 今回の結果もこれを文持している.これら程類の種類と 量的関係がここで得られた結果のように，植物の種類に よって抽出液の影響に若干の差を与える結果になった原 因の一つと考えられる。亦た，でさるだけ生体内に近い 条件で実験を行なうことを目的としたが，酵素作用を止 める必要から加熱処理したために，大部分の蛋白質を除 去した抽出液を使用した結果となり，蛋白筫の影學を調 べることはできなかった，これは，今後検討されるべき 問題である5。

このように実験上の困難から，生体内でデンプンが生 成する祭の条件を，上の実験条件とを一致させることが できなかったためもあるが，天然デンプンの結晶形とそ の植物からの抽出液の影響とが必ずしも一致していな い.とくに典型的なB図形のデンプン粒を作るジャガイ モの抽出液が，アミロデキストリンの結晶をB形よりむ しろA形の方へ近づける作用を示すことは興味がある. 
植物体では，デンプンは常に粒として存在し，微嘼で も溶けた状態で存在することが観察されていない。これ は，デンプン分子が合成されたときには，直ちに沈殿し て粒になり，その分はその粒に付加的に沈着するためと 考光られる.このように，デンプンをすみやかに沈殿さ せる原因について現在不明な点が多いが，植物細胞中に 何かの因子があるものと思われる．第3表の実験結果代 示す上5に，水の場合と比較して，アミロデキストリン の沈唭量が著しく多いことからも，植物抽出液にはアミ ロデキストリン分子を沈皘させやすい作用があるように 思わ机る．このアミロデキストリンの結晶化を促進する 物質と、結晶形をA形の方へ押しやる物質とが同一物で あるか否かは，まだ明らかでない，しかし無機イオンの 影響から考克て，溶夜中の水分を吸着する作用の強い物 質があれば，結果的には瀑度を上げたこととなり，結晶 の量も多くなり，結晶形もA形に傾くであるう。

要 約

市肘の酒造用のデキストリンシラップから分離した結 晶性のアミロデキストリンを，種々の植物抽出液を用い て再結晶し，その結晶形をX線ディフラクトメーターで 調ベた。

その結果，植物抽出液の代わりに水を用いた場合には， 植物抽出液中の固形物量汇相当するアミロデキストリン 量を增した場合にも， $C_{B}$ 形の結晶形のものが得られ た．これに対し植物抽出液を用いると，いずれの場合る 結晶形が水の昜合よりもA形の方向に变化することが認 められた．この結晶形を変化させる物質につき， 2,3 の 考察を行なった.

また水溶液の昜合に比べて，植物抽出液ではアミロデ
キストリンの沈殿量が著しく多い，したがって，植物抽 出液沈アミロデキストリンの沈殿を促進ざせ，しかる その結晶形を $\mathrm{A}$ 形に近づる性質があり，その程度は 植物の程類によってかなり相遀することが明らかになっ た.

終りに，サッマイモを提供された三重大学農学部, 前 田厥氏と純結晶 $\beta$ ーフミラーゼを分与された鹿児島大学 農学部，竹田靖史氏に謝意を表する。 また本実験の費用 の一部は文部省科学研究費，田辺製薬株式会社研究費に あ扔いだ、あわせて感謝する。

な扰，本報の要旨は昭和 43 年 4 月名古屋大学におけ る日本農芸化学会大会に拈いて発表した。

(1) S. Hizukuri, M. Fuzii and Z. Nikuni : Nature, 192, 239 (1961).

(2) S. Hizukuri, M. Fuzii and Z. Nikuni : Stärke, 17, 40 (1965).

（3）檜作 進，前田 政，熊谷寛次，土井健二，二 国二郎, 森脇 勉, 長谷川浩 : 日本農芸化学会 講演要旨集, 213 (1966).

（4）熊谷寬次，㭘作 進，二国二郎，長谷川浩，森 勝 勉 : 日本農芸化学会関西支部第 120 回例会 要旨 $(1967)$.

（5）檜作 進，二国二郎，服部保綱，和田収作：農 化, 33, 615 (1960).

(6) M. Somogyi : J.B.C., 195, 19 (1952).

(7) O. H. Lowry, N. J. Rosebrough, A. L. Farr, and R. J. Romdal : J. Biol. Chem., 193, 265 (1961).

(8) S. Hizukuri : Agr. Biol. Chem., 25, 45 (1961).

（9）榔作 進, 藤井ミ+子, 二国二郎：Biochim. Biophys. Acta, 40, 246 (1960). 